\title{
PERTUMBUHAN BAKTERI Pseudomonas solanacearum E.F. Smith PADA PEMBERIAN EKSTRAK URANG ARING
}

\author{
GROWTH OF BACTERIA Pseudomonas solanacearum E.F. Smith ON EXTRACTS OF \\ URANG ARING (Eclipta alba)
}

\author{
Parluhutan Siahaan*) \\ "Jurusan Biologi Fakultas MIPA Universitas Sam Ratulangi Manado \\ Email Korespondensi: luhut.siahaan68@yahoo.co.id
}

\begin{abstract}
Pseudomonas solanacearum is a bacterium that causes wilt disease in tomato, peppers, tobacco, potatoes and Solanaceae plants in general. The bacteria attacks their hosts in nearly all phases of development. Young plants are usually more vulnerable and the bacteria tends to grow faster. The use of synthetic pesticides for controlling the disease could cause many negative impact on human and environment, Hence, it is necessary to find an environmentally friendly pesticides for controlling the disease. Urang aring (Eclipta alba L. Hask.) contains bioactive compounds that potential to be used as botanical pesticides. This research was conducted to evaluate the effect of ethanol extracts of urang aring (Eclipta alba L. Hask.) to inhibit the growth of Pseudomonas solanacearum. Bioassay was done by deluting extracts to make concentration $1 \%, 2 \%, 3 \%, 4 \%(\mathrm{w} / \mathrm{v})$. The result showed that ethanol extracts inhibited the growth of $P$. solanacearum starting at concentration $1 \%$ with inhibition zone diameter $10,7 \mathrm{~mm}$. At level $4 \%$ concentration (inhibition zone diameter $17.59 \mathrm{~mm}$ ) were not significant difference with agrmicyn $0.03 \%$, a synthetical bactericidal with inhibition zone diameter $18,31 \mathrm{~cm}$. The results of this study revealed that urang aring was potential as botanical pesticide.
\end{abstract}

Keywords: Urang Aring, Eclipta alba, Pseudomonas solanacearum

\section{ABSTRAK}

Pseudomonas solanacearum adalah bakteri yang menyebabkan penyakit layu pada tomat, cabai, tembakau, kentang dan tanaman Solanaceae secara umum. Bakteri ini dapat menyerang tuan rumah mereka di hampir semua tahap pembangunan. Pada tanaman muda biasanya lebih rentan dan cenderung tumbuh lebih cepat. Penggunaan pestisida sintetik untuk mengatasi penyakit ini menyebabkan dampak negatif terhadap manusia dan lingkungan, sehingga perlu untuk menemukan pestisida ramah lingkungan. Urang Aring (Eclipta alba L. Hask.) Mengandung senyawa bioaktif yang berpotensi untuk digunakan sebagai pestisida botani. Penelitian ini dilakukan untuk mengevaluasi pengaruh ekstrak etanol urang Aring (Eclipta alba L. Hask.) Untuk menghambat pertumbuhan bakteri Pseudomonas solanacearum. Bioassay dilakukan dengan deluting ekstrak untuk membuat konsentrasi $1 \%, 2 \%, 3 \%, 4 \%(\mathrm{~b} / \mathrm{v})$. Hasil penelitian menunjukkan bahwa ekstrak etanol menghambat pertumbuhan P. solanacearum mulai pada konsentrasi $1 \%$ dengan diameter hambatan $\mathrm{mm}$ zona 10,7 . Pada konsentrasi $4 \%$ (diameter daerah penghambatan $17,59 \mathrm{~mm}$ ) tidak berbeda nyata dengan agrmicyn $0,03 \%$, suatu bakterisida kimis dengan diameter zona hambatan $18,31 \mathrm{~cm}$. Hasil penelitian ini menunjukkan bahwa Aring urang memiliki potensi untuk dikembangkan menjadi pestisida botani.

Kata kunci: Urang Aring, Eclipta alba, Pseudomonas solanacearum 


\section{PENDAHULUAN}

Bakteri Pseudomonas solanacearum adalah bakteri yang menyebabkan penyakit layu pada tanaman tomat, cabai, tembakau, kentang dan tanaman suku Solanaceae pada umumnya. Menurut Gunawan (1987) tanaman tomat dan kentang yang ditanam pada ketinggian 700-800 di atas permukaan laut yang terserang penyakit layu ini dapat mencapai kehilangan hasil sampai $60-100 \%$, sedang bila ditanam di daerah pertanian Lembang (Jawa Barat) dengan ketinggian 1000-1200 di atas permukaan laut kehilangan hasilnya dapat mencapai 15$40 \%$.

P. solanacearum dapat menyerang inangnya hampir pada semua fase perkembangannya. Pada tanaman muda biasanya lebih rentan dan cenderung lebih cepat berkembang (Mehrota, 1983). Serangan terjadi pada pembuluh xylem tanaman, sehingga akan menyebabkan rusaknya jaringan ini dan akibatnya transportasi air ke daun akan terhambat. Terhambatnya aliran air ini akan mengakibatkan terganggunya proses fotosintesis dalam daun, sehingga tidak dihasilkan makanan dan tidak dapat megimbangi penguapan yang terus terjadi.

Penyakit ini berdampak besar terhadap pertumbuhan tanaman tomat sehingga sangat merugikan bagi petani. Pemberantasan bakteri ini pada tanaman tomat biasanya dengan bakterisida agrimycin dengan cara menyiramkannya ke tanah sekitar tanaman (Samadi, 1996).

Pemakaian pestisida sintetik untuk mengendalikan hama dan penyakit merupakan cara yang paling banyak digunakan, karena terbukti sangat cepat, praktis dan efektif, akan tetapi membawa efek negatif yaitu membunuh organisme sasaran seperti organisme yang membantu penyerbukan, musuh alaminya sendiri atau organisme non target lain, sehingga dapat menimbulkan gangguan pada ekosistem (Van den Bosch et.al., 1982). Menurut Samways (1981) pestisida sintetik itu sukar terdegradasi secara alami sehingga mencemari lingkungan dan sering residunya terdapat pada hasil panen sehingga akibatnya mengganggu kesehatan manusia, sehingga mengakibatkan resurgensi, peledakan hama kedua dan terjadi resistensi.
Melihat akibat buruk yang ditimbulkan oleh pestisida sintetis, maka pemerintah Indonesia telah mengambil kebijaksanaan dengan Keputusan Presiden No. 7/1973 yang mengatur tentang penggunaan pestisida. Berbagai jenis pestisida mulai ditarik dari peredaran, sejak tahun 1976 hingga 1994 sudah sebanyak 69 formulasi yang terdiri atas 22 bahan aktif dinyatakan dilarang beredar (Ekha, 1988).

Akhir-akhir ini perhatian terhadap pestisida yang ramah terhadap lingkungan semakin meningkat. Salah satu pestisida yang ramah terhadap lingkungan adalah pemanfaatan senyawa-senyawa bioaktif dari yang berasal dari tumbuhan yang sering disebut pestisida botani atau pestisida nabati. Pestisida botani mengandung senyawa yang mudah terdegrasi di alam. Salah satu tumbuhan yang berpotensi untuk dimanfaatkan adalah tumbuhan urang aring (Eclipta prostata). Tumbuhan ini merupakan tumbuhan yang mudah diperoleh karena penyebarannya yang luas dan mudah untuk dikembangbiakkan. Selain itu mengandung senyawa-senyawa bioaktif yang potensial (Manurung, 1986).

Kandungan senyawa bioaktif tumbuhan urang aring antara lain golongan flavonoid, alkaloid, saponin, tanin, sterol dan terpenoid. Identifikasi dengan kromatografi menunjukkan dua senyawa flavornoid yaitu epigenin dan epigenin-7-0-glukosida. Ekstraknya mengandung beberapa asam fenolat seperti asam $p$-hidroksi benzoat, asam $p$-kumarat dan asa klorogenat (Manurung, 1986).

Potensi tumbuhan $E$. prostata sebagai agen anti serangga pernah diteliti Sastrodihardjo \& Adianto (1983) mereka menemukan bahwa ekstrak urang aring ternyata dapat mengendalikan serangga hama wereng. Hasil penelitian Lydia (1991) menunjukkan ekstrak etanol urang aring dapat menghambat aktivitas dan pertumbuhan bakteri Staphylococcus aureus dan Escherichia coli.

Melihat potensi tersebut maka tujuan dari penelitian ini adalah untuk mengetahui pengaruh senyawa bioaktif yang terkandung dalam ekstrak urang aring (Eclipta alba) terhadap pertumbuhan Bakteri $P$. solanacearum. 


\section{METODE PENELITIAN}

Penelitian ini menggunakan metode eksperimental dan pengamatan dilakukan terhadap diameter pertumbuhan koloni jamur dengan empat kali pengukuran pada 4 arah yang berbeda. Rancangan percobaan yang dilakukan adalah Rancangan Acak Lengkap (RAL) dengan 5 perlakuan dan masing-masing 4 ulangan serta 2 sub ulangan (dalam satu cawan petri terdapat dua cetakan hifa jamur).

\section{Ekstraksi Urang Aring}

Bagian tumbuhan yang akan digunakan untuk ekstraksi adalah daun, bunga, batang dan akar. Bahan dibersihkan dan dikeringkan dengan cara diangin-anginkan di tempat terbuka tanpa terkena cahaya matahari secara langsung. Setelah menjadi kering dipotong kecil-kecil agar mudah dimasukkan ke dalam mesin penggilingan. Selanjutnya digiling sampai berbentuk serbuk halus untuk memudahkan pelarut melakukan penetrasi pada saat ekstraksi.

Sebanyak satu kilogram serbuk dimasukkan ke dalam tabung kemudian direndam dengan 4 liter etanol selama dua kali 24 jam pada suhu kamar. Serbuk yang direndam disaring dan ampasnya dimaserasi kembali sampai beberapa kali hingga filtratnya relatif tidak kental. Filtratnya disatukan dan pelarutnya diuapkan dengan memasukkannya ke dalam rotavapor pada suhu $40^{\circ} \mathrm{C}$ sampai diperoleh ekstrak etanol kental. Ekstrak kental ini dikeringkan di atas penangas air pada $40^{\circ} \mathrm{C}$ sehingga diperoleh ekstrak etanol kering (Soetarno, 1992).

Ekstrak etanol kering dihidrolisis basa tujuannya untuk memisahkan ikatan gula dari senyawa bioaktif dengan cara sebagai berikut. Ekstrak etanol tersebut dilarutkan dalam metanol-air (1:9) lalu ditambahkan larutan natrium hidroksida $(\mathrm{NaOH}) 2 \mathrm{~N}$ sampai menjadi $1 \mathrm{~N}$. Selanjutnya larutan didiamkan di dalam ruang gelap pada suhu kamar selama 24 jam agar reaksi tidak terganggu cahaya, hal ini dilakukan untuk memisahkan bahan aktif yang berupa aglikon dari gulanya. Hasil hidrolisis ditambah asam sulfat (H2S04) 10\% agar larutan netral kembali. Pelarut ekstrak yang diperoleh diuapkan kembali dengan rotavapor yang dilanjutkan di atas penangas air pada suhu $40^{\circ} \mathrm{C}$ sampai diperoleh ekstrak etanol terhidrolisis kering.

\section{Uji Hayati Secara in vitro}

Pertama-tama dilakukan perbanyakan bakteri yaitu dengan meninokulasikan bakteri yang diperoleh dari Balitsa Lembang ke dalam Nutrien Broth lalu diinkubasikan pada suhu $28^{\circ} \mathrm{C}$ di dalam shaker dengan kecepatan rotasi 110 rotasi/menit selama 24 jam.

Medium NA yang telah disediakan dicairkan, pada saat suhu kira-kira $40^{\circ} \mathrm{C}$ lalu $1 \mathrm{ml}$ suspensi bakteri dan segera dimasukkan ke dalam cawan petri steril, digoyang-goyang sampai bakteri relatif merata dan dibiarkan membeku.

Ekstrak urang aring dilarutkan untuk membuat konsentrasi 1,0\%, 2,0\%,3,0\% dan 4,0\% (b/v) dan sebagai kontrol hanya aquades. Lalu kertas cakram yang steril dicelupkan pada setiap konsentrasi larutan ekstrak itu selama 5 menit, kemudian diletakkan di atas medium yang telah mengandung bakteri. Pada setiap cawan petri diletakkan 2 kertas cakram kemudian diinkubasikan pada suhu $30^{\circ} \mathrm{C}$ selama $1 \times 24$ jam.

Aktivitas senyawa bioaktif yang terdapat di dalam ekstrak untuk menghambat pertumbuhan bakteri dilihat dari diameter zona terang atau daerah bening yang terbentuk di sekitar kertas cakram. Zona terang atau daerah bening menunjukkan daerah yang tidak ditumbuhi oleh bakteri (McKane \& Kandel, 1986). Diameter diukur empat kali dari arah yang berbeda (Gonzales et.al., 1989).

\section{Analisis Data}

Data hasil pengukuran terhadap diameter area pertumbuhan jamur dianalisis dengan metode analisis sidik ragam (ANOVA) dan selanjutnya dianalisis dengan uji beda nyata terkecil (LSD) pada taraf 0,05 untuk antar konsentrasi.

\section{HASIL DAN PEMBAHASAN}

Daya hambat atau kemampuan toksisitas ekstrak etanol diketahui berdasarkan diameter daerah bening atau zona terang yang terbentuk di sekeliling kertas cakram, seperti yang terlihat pada Gambar 2. Data hasil pengukuran rata-rata diame- 
ter zona hambatan dapat dilihat dalam Tabel 1 dan histogramnya ditunjukkan pada Gambar 1.

Dari data yang tertera dalam Tabel 1 dan Gambar 1 tampak bahwa aktivitas hambatan mulai tampak pada konsentrasi 1,0\% yang mempunyai rata-rata diameter daerah hambatan sebesar 10,77 $\mathrm{mm}$. Diameter daerah hambatan semakin besar dengan bertambahnya konsentrasi ekstrak. Diameter daerah hambatan tertinggi karena pengaruh ekstrak terjadi pada konsentrasi 4\% yaitu sebesar 17,59 $\mathrm{mm}$. Diameter daerah hambatan yang tertinggi dari semua perlakuan adalah dengan pemberian Agrimcyin yaitu suatu bakterisida sintetik yang mempunyai rata-rata diameter hambatan sebesar $18,02 \mathrm{~mm}$ pada konsentrasi $0,01 \%$.

Pengujian secara statistik dengan Uji beda Nyata Terkecil pada taraf kepercayaan 0,05 menunjukkan bahwa perbedaan diameter hambatan antar perlakuan sampai konsentrasi ekstrak 4,0\% adalah berbeda nyata, kecuali antara agrimycin 0,01\% dengan ekstrak 4,0\% tidak berbeda nyata.

Berdasarkan kenyataan tersebut memang bakterisida agrimycin lebih efektif menghambat pertumbuhan bakteri $P$. solanacearum dibanding dengan ekstrak fraksi etanol tumbuhan urang aring. Hanya dengan konsentrasi 0,01\% agrimicyn sudah menunjukkan toksisitas yang hampir sama dengan konsentrasi 4,0\% ekstrak etanol urang aring.

Perbedaan konsentrasi dengan efek yang hampir sama ini mungkin karena kandungan senyawa bioaktif yang terdapat pada dalam ekstrak etanol dalam jumlah yang kecil, ekstrak etanol masih merupakan ekstrak kasa yang masih mengandung senyawa-senyawa lain yang bukan merupakan senyawa bioaktif atau mengandung senyawa bioaktif yang lain tetapi tidak toksik terhadap bakteri $P$. solanacearum.

Tabel 1. Rata-rata Diameter Hambatan Pertumbuhan Bakteri $P$. Solanacearum Akibat Pemberian Ekstrak Etanol Tumbuhan Urang Aring Setelah Inkubasi $1 \times 24$ jam

(Table 1. The Average Diameter of Bacterial Growth Inhibition of P. Solanacearum Due to Plant Ethanol Extract Urang Aring $1 \times 24$ Hours After Incubation)

\begin{tabular}{llllllr}
\hline & \multicolumn{7}{c}{ Konsentrasi (\%) } \\
\hline & 0,0 & 1,0 & 2,0 & 3,0 & 4,0 & Ag 0,01 \\
\hline Diameter & 6.00 & 10.77 & 12.74 & 15.45 & 17.59 & 18.31 \\
Hambatan & \pm 0.00 & \pm 0.55 & \pm 0.50 & \pm 0.74 & \pm 0.46 & \pm 0.95 \\
Rata-rata \pm s.d & $\mathrm{a}$ & $\mathrm{b}$ & $\mathrm{C}$ & $\mathrm{d}$ & $\mathrm{e}$ & $\mathrm{e}$ \\
\hline
\end{tabular}

Keterangan :

Huruf di bawah angka rata-rata yang sama berarti tidak beda nyata menurut uji LSD pada taraf 0,05 Ag 0,01 = bakterisida agrimycin s. $d=$ standard deviasi

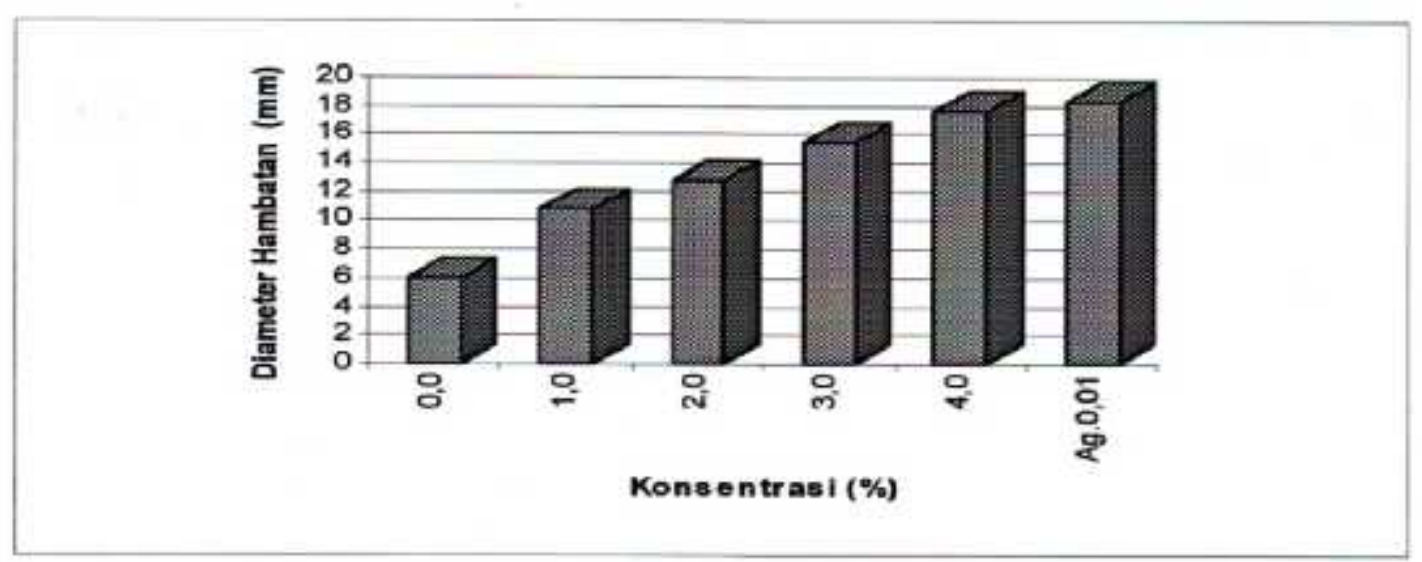

Gambar. 1. Histogram Diameter Hambatan Pertumbuhan Bakteri P. solanacearum Setelah Perlakuan $1 \times 24$ jam

(Figure 1. Histogram of the Diameter of Bacterial Growth Inhibition of P. solanacearum After Treatment $1 \times 24$ hours) 


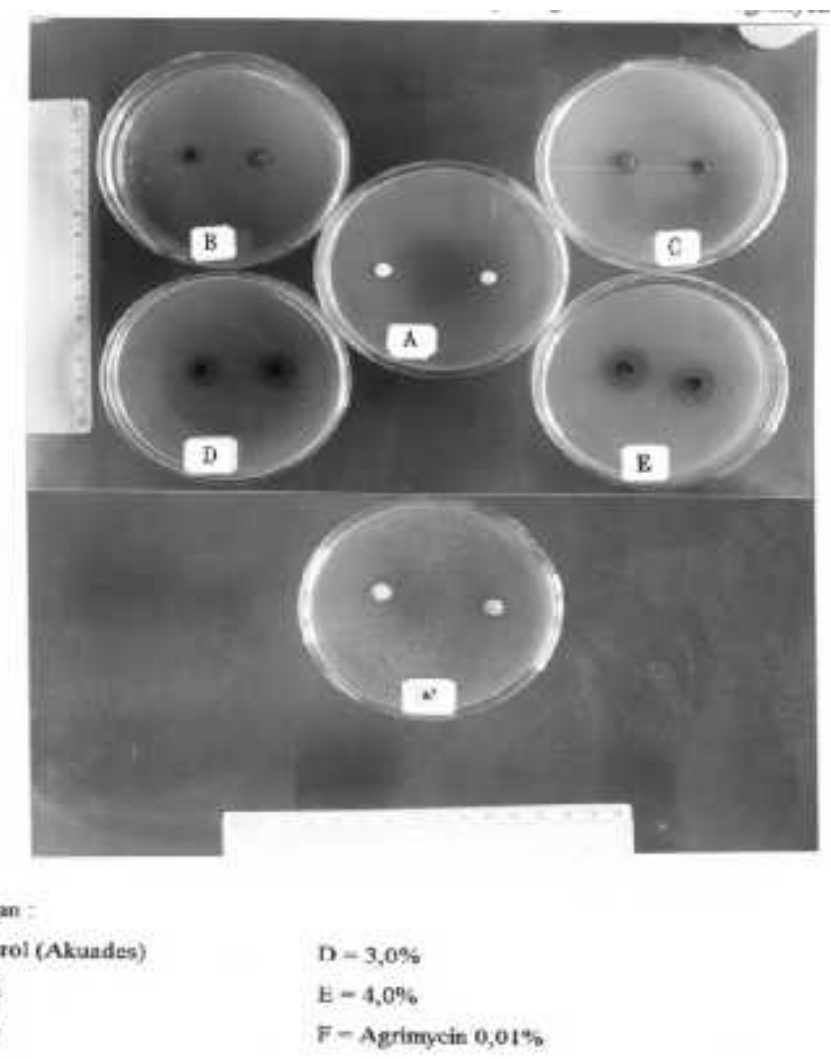

Gambar 2. Diameter Daerah Hambatan Pertumbuhan Bakteri P. solanacearum yang Dipengaruhi Ekstrak Etanol Tumbuhan Urang Aring dan Bakterisida Agrimicyn

(Figure 2. Diameter of Bacterial Growth Inhibition of P. solanacearum Ethanol Extracts of Plants Affected Urang Aring and Bactericidal Agrimicyn)

Senyawa bioaktif yang terkandung dalam tumbuhan urang aring yang dapat ditarik oleh pelarut etanol antar lain senyawa golongan terpenoid. Golongan terpenoid yang terdapat dalam tumbuhan urang aring antara lain, saponin, (Manurung, 1986), triterpenoid alfa amirin, steroid stigmasterol (Govindachari, 1975) dan sterol (Halim et al., 1982). Senyawa inilah yang diduga menghambat partumbuhan bakteri $P$. solanacearum. Stowe \& Kil (1983) menyatakan senyawa terpenoid dan turunannya tidak tersebar luas pada dunia tumbuhan sebagaimana senyawa golongan fenolat, tetapi mereka memiliki potensi yang tinggi sebagai agen alelopati, karena senyawa terpenoid dapat bersifat toksik sampai konsentrasi yang sangat rendah (1-3 X 10 M). Robinson (1983 dalam Rice, 1984) melaporkan bahwa senyawa terpenoid bersifat toksik terhadap pertumbuhan terhadap bakteri tertentu.

Hasil penelitian ini didukung oleh laporan Lydia (1991) yang menyatakan ekstrak urang aring dapat menghambat pertumbuhan bakteri
Staphylococcus aureus dan Escherichia coli. Govindachari (1975) mengatakan wedelakton yang berasal dari tumbuhan urang aring merupakan senyawa turunan terpenoid yang dapat bersifat antibakteri. Laporan Siddiqui et al. (1988) menyatakan senyawa diterpenoid dari kulit kayu Azadirachta indica menunjukkan aktivitas antibakteri terhadap bakteri gram positif Bacillus subtilis, Staphylococcus epidermidis dan S. aureus dan juga terhadap bakteri gram negatif Klebsiella ozaenae. Hasil penelitian yang dilakukan oleh Sidik (1993) dilaporkan bahwa ekstrak dari Plantago major yang diduga mengandung senyawa terpenoid dapat menghambat pertumbuhan bakteri $P$. solanacearum.

Senyawa golongan terpenoid menurut Harbone (1983) bekerja pada tingkat seluler dan mempengaruhi fungsi plamalemma. Lorber dan Muller (1976 dalam Stowe \& Kil, 1983) mengatakan jumlah organel yang lengkap termasuk mitokondria akan berkurang dengan pemberian terpen, selain 
itu membran sekeliling inti, mitokondria dan diktiosom sering menjadi rusak. Muller (1969 dalam Stowe \& Kil, 1983) membuktikan bahwa terpenoid dapat menghambat proses-proses yang ada dalam tumbuhan dengan memlokir respirasi sel.

Terbukti dengan konsentrasi $1,2 \times 10 \mathrm{M}$ sineol (terpenoid) menurunkan pengambilan oksigen oleh mitokondria. Penghambatan tampaknya pada saat mengkonversi suksinat menjadi fumarat atau fumarat menjadi malat. Akibat dari hal tersebut maka proses metabolisme di dalam sel tidak berjalan dengan sebagaimana mestinya, sehingga sel bakteri akan kekurangan nutrisi dan akhirnya bakteri menjadi mati. Dengan demikian penghambatan pertumbuhan bakteri $P$. solanacearum kemungkinan karena adanya senyawa terpenoid dalam ekstrak etanol tumbuhan urang aring.

\section{KESIMPULAN}

Berdasarkan hasil penelitian yang telah dilakukan, dapat disimpulkan bahwa: 1) Ekstrak etanol tumbuhan urang aring mampu menghambat pertumbuhan bakteri $P$. solanacearum secara in vitro mulai dari konsentrasi $1 \%(\mathrm{~b} / \mathrm{v})$. Semakin tinggi konsentrasi ekstrak semakin besar diameter zona hambatan yang terbentuk, hal ini menunjukkan bahwa ekstrak urang aring dapat menghambat partumbuhan bakteri $P$. solanacearum. 2) Ekstrak etanol tumbuhan urang aring pada konsentrasi $4 \%$ mempunyai daya hambat yang sama dengan daya hambat bakterisida agimycin $0,01 \%(\mathrm{~b} / \mathrm{v})$. Konsentrasi yang sangat berbeda dengan bakterisida sintetik disebabkan oleh kandungan pada ekstrak etanol urang aring masih bersifat ekstrak kasar sehingga ekstrak masih mengandung senyawa-senyawa lain yang tidak bersifat tidak toksik terhadap bakteri $P$. solanacearum. 3) Ekstrak etanol tumbuhan urang aring berpotensi untuk dieksploitasi untuk menjadi pestisida botani.

\section{DAFTAR PUSTAKA}

Ekha, I. 1988. Dilema Pestisida. Tragedi Revolusi Hijau. Kanisius. Yogyakarta.
Fravel, D. Olivain, C. \& Alabouette, C. 2003. Fusarium oxysporum and its biocontrol. New Phytologist 157 (3). pp 493-502

Gunawan, O.S. 1987. Pengendalian Penyakit layu bakteri (Pseudomonas solanacearum) pada tanaman kentang dengan agrimisin. Bull. Penel.Horti. 15 (4).p. 45-48

Gonzales, A.G.; Abad, T.; Jimenez, I.A.; Ravelo, A.G., Luis, J.G.; Aquiar, Z.; Andres, L.S.; Plasencia, M..; Herera, J.R.; Moujir, L. 1989. A First Study of Antibacterial Activity of Deterpenes Isolated from some Salvia Species (Lamiaceae). Biochem. Syst. and Ecol. $17: 4$ p. 293-296.

Harbone, J.B., 1983. Toxin of Plant - Fungal Interaction in : Plant and FungalToxin. Decker Inc. New York.

Halim, A.F., Balbaa, S.I \& Khalil, A.T. 1982. Phenolics and Other Constituents from Eucaliptus alba. Planta Med. (45). p.41

Lydia, B. 1991. Penapisan Aktivitas Antibakteri dan Fungi Ekstrak Etanol Tanaman Suku Compositae. Skripsi Sarjana Jurusan Farmasi ITB. Bandung.

Manurung, R.M. 1986. Pemeriksaan Senyawa Fenolik Herba Urang Aring (Eclipta alba (L). Hassk compositae). Skripsi sarjana Jurusan Farmasi ITB. Bandung.

Mehrota, R.S., 1982. Plant Pathology. Tata Mc Graw - Hill Publishing.

Rice, E.L. 1984. Allelopathy. Academic Press. Inc. Orlando. Florida

Samadi, B. 1996. Pembudidayaan Tomat Hibrida. C.V. Aneka Solo.

Samways, M.J. 1981. Biological Control of Pests and Weeds. Edward Arnold (Publishers) Limited London.

Sastrodiharjo, S \& Adianto 1983. Mengembangkan Ekstrak Tanaman Eclipta alba dan Azadirachta indica Untuk Pengendalian Hama Wereng. Laporan Penelitian Biologi. ITB Bandung.

Siddiqui, S., Ara, I., Faizi, S., Mahmood, T. \& B.S. Siddiqui. 1988. PhenolicTricylic Diterpenoids from the bark of Azadirachta indica. Phytochemistry. 27 (12) : 3903 3907 
Sidik, P. 1993. Pengaruh Ekstrak Ici Urat (Plantago Mayor) terhadap pertumbuhan tanaman tomat dan serangannya oleh Bakteri Pseudomonas solanacearum E.F. Smith. Tesis Pascasarjana Biologi ITB. Bandung.

Soetarno, S. 1992. Pengembangan Teknik Pembuatan Sediaan Produk Bahan Alami untuk Pestisida. PAU IImu Hayati ITB.

Stowe, L.E. \& Kil, B.S. 1983. The Role of Toxin in Plant. Plant interaction in: Plant and Fungal Toxin. Decker Inc. New York.
Van den Bosch, R, Messenger, P.S \& Guiterrez, A.P. 1982. An Introduction to Biological Control. Plenum Press. New York.

Vickery, L.M. \& Vickery, B. 1981. Secondary Plant Metabolism. The Macmillan Press Ltd. London. 
